\title{
Bir Kamu Üniversitesi Çalışanlarında Aktif ve Pasif Sigara İçicilik Durumu, Bağımııık Düzeyi ve Değişimin Aşamaları
}

\author{
Status of Active and Passive Smoking, Addiction Level and Stages of Change at Public \\ University Employees
}

\author{
Gülnaz KARATAY ${ }^{\mathrm{a}}$, Nazan GÜRARSLAN BAŞ ${ }^{\mathrm{b}}$
}

\begin{abstract}
ÖZ Amaç: Bu çalışmanın amacı bir kamu üniversitesinde çalışanların aktif ve pasif sigara içicilik durumunu, bağımlılık düzeyini ve içinde bulunduğu değişimin aşamasını değerlendirmektir. Yöntem: Tanımlayıcı türden yapılan bu çalışmanın evrenini 2015-2016 öğretim yılında Türkiye'nin doğusunda bir üniversitede görev yapan akademik, idari ve diğer personeller oluşturdu. Evrenin tamamı örneklem kapsamına alınmış olup, 230 (evrenin \%57.5'i) çalışandan elde edilen veriler değerlendirmeye alındı. Araştırmanın verileri "Üniversite Çalışanlarında Sigara Bağımlılığı Soru Formu", "Fagerström Nikotin Bağımlıllk Testi" ve sigara için uyarlanmış "Değişim Aşamaları Testi " kullanılarak toplandı. Elde edilen veriler, bilgisayar destekli SPSS 18.0 programında sayı, yüzdelikler ve önemlilik testi olarak da ki-kare kullanılarak analiz edildi. Bulgular: Çalışmaya katılan bireylerin \%16.5'i ara sıra, \%30.4 ünün düzenli olarak sigara içtiğini, \%10.4'ü ev ortamında, \%23.9'u ise iş yerinde pasif sigara dumanına maruz kaldığını ifade etti. Kadınlarda ve akademisyenlerde sigara içme oranları daha fazla iken, diğer çalışanların pasif sigara dumanına daha fazla maruz kaldığı görüldü $(p<.05)$. Katılımcıların \%37.6'sında orta düzeyde, \%16.8'inde ise ileri düzeyde nikotin bağımlılığı olduğu ve \%42.4'ünün sigara bırakma ile ilgili niyet öncesi aşamada ve \%32.7'sinin niyet aşamasında olduğu saptandı. Sonuç: Bu çalışmada elde edilen bulgulara göre üniversite çalışanlarının yarıya yakını aktif sigara içicisi olup, yaklaşık her beş çalışandan birinin pasif sigara dumanına maruz kaldığı, kadınlarda ve akademisyenlerde sigara bağımlılığının daha fazla olduğu görüldü.
\end{abstract}

Anahtar Kelimeler: Sigara, üniversite çalışanları, prevalans.

\begin{abstract}
Aim: The aim of this study was evaluated the status of active and passive smoking, the level of dependence and the stage of change that they were in at a public university. Method: The universe of this descriptive study was being composed of academic, administrative and other employees working in a university in the east of Turkey in the academic year of 2015-2016. All of the universe was included in the sample and 230 (\% 57.5 of the universe) data obtained from the employees were evaluated. The data of the study were collected using the "Cigarette Dependency Questionnaire in University Personnel", "Fagerström Nicotine Dependence Test" and "The Stages of Change Test" adapted for smoking. The data were analyzed by using chi-square as the number, percentages and significance test entered into the computer-aided SPSS 18.0 program. Results: $16.5 \%$ of the employees participating in the study stated that they occasionally smoke $30.4 \%$ of their smoking regularly, $10.4 \%$ stated that they were exposed to passive smoking at work and $23.9 \%$ at the workplace. While smoking rates were higher in women and academics, workers were more exposed to passive smoking $(\mathrm{p}<.05)$. It was determined that $37.6 \%$ of participants had nicotine addiction at moderate level, $16.8 \%$ had advanced nicotine addiction and $42.4 \%$ were in the pre-intention stage of smoking cessation and $32.7 \%$ were in the intention stage of change. Conclusion: According to the findings obtained in this study, nearly half of the university employees were active smokers, one of every five employees was exposed to passive smoking and smoking habits were more frequent among women and academics.
\end{abstract}

Key Words: Smoking, university employees, prevalence.

\section{Giriş}

Epidemik salgına dönüştüğü için küresel bir sorun haline gelen sigara tüketimi ve buna bağlı sorunlar dünyada ölüm nedenleri, özellikle de prematür ölüm nedenleri arasında ilk sıralarda yer almaktadır. Dünyada her yıl 6 milyon insan tütün ürünleri kullanımı, 600.000 kişi ise pasif sigara dumanına maruziyet nedeniyle yaşamını yitirmektedir. ${ }^{1}$ Ancak sigaranın uzun süreli etkilerinin bilimsel olarak daha iyi ortaya konmasıyla birlikte özellikle gelişmiş ülkelerde uygulanan sigarasızlık politikalarının etkisiyle sigara prevalansı düşme trendine girmiştir.

Geliş Tarihi/Received: 22-06-2017/ Kabul Tarihi/Accepted:01-11-2017

a Doç.Dr. Munzur Üniversitesi,Sağlık Yüksekokulu-TUNCELİ, ,e-mail: gkaratay@ gmail.com

b Yrd.Doç.Dr.Munzur Üniversitesi,Sağlık Yüksekokulu-TUNCELİ, e-mail:nbas@ munzur.edu.tr, ORCID ID: 0000-0002- 6488-0890

Sorumlu yazar /Correspondence: Yrd. Doç. Dr. Nazan GÜRARSLAN BAŞ, Munzur Üniversitesi,Sağlık YüksekokuluTUNCELİ, ,e-mail:nbas@munzur.edu.tr 
Türkiye de sigara prevalansının düşme eğilimi gösterdiği ülkeler arasındadır. Küresel Yetişkin Tütün Araştırması Türkiye 2012 raporuna göre 2008 ile 2012 yılları arasında Türkiye'de tütün kullanım prevalans1 \%31.2'den $\% 27.1$ 'e gerile-miştir. ${ }^{2}$

Sigara yedi binden fazla kimyasal madde içermektedir ve bu maddeler vücut dokularına derinlemesine nüfuz ederek inflamasyona ve hasara yol açmaktadır. Ağız ve akciğerler üzerinden, kan damarlarına, kalbe, beyne ve diğer dokulara ulaşarak DNA hasarına ve sitotoksik değişikliklere yol açıp, damar yapısını bozmakta ve inflamasyon nedeniyle vücudun sürekli alarm seviyesinde kalmasina yol açmaktadır. Ayrıca, yaklaşık olarak yetmişe yakın kanserojen madde içeren sigara, akciğer kanseri başta olmak üzere bütün organ kanserlerinin en önemli nedenleri arasında yer almaktadır. ${ }^{3}$ Sigara, orta yaş yetişkinlerde kalp damar hastalıklarına bağlı ölümlerin \%25'inden sorumludur. ${ }^{4}$ Fizyolojik sağllğa etkilerinin yanında psikolojik, sosyal ve ekonomik açıdan da kayıplara neden olan sigara ülkemizde her yıl 120 bin kişinin yaşamını yitirmesine neden olmaktadır. ${ }^{5} \mathrm{Bu}$ tabloya pasif maruziyete bağlı sorunlar da eklenince sigaranın toplumsal maliyeti oldukça artmaktadır.

İnsan sağlığını bozan bir diğer etken, çevresel sigara dumanı maruziyetidir. Bireyler sigara içmeseler bile sigara içilen ortamlarda pasif sigara dumanına maruziyete bağl1 sağl1k sorunları yaşayabilmektedir. ${ }^{3}$ Amerika' da 20102011 yılları arasında 58 milyon sigara içmeyen birey, kiralık evlerde yaşayan her 3 kişiden biri pasif sigara dumanına maruz kaldığını ifade etmiştir. Özellikle düşük gelir gruplarında bu riskin daha fazla olduğu ifade edilmektedir. ${ }^{6}$ Türkiye'de ise Battal ve diğerlerinin (2009) çalışmasında kadınların \%65.6'sı ev ortamında, \%64.7'sinin ise ev dışında pasif sigara dumanına maruz kaldığ belirtilmektedir. $^{7}$ Karatay (2008) tarafindan yürütülen bir çalışmada çocukların \%70.8'inin ev ortamında babalarının içtiği sigara dumanına maruz kaldığı görülmüştür. ${ }^{8}$ Dolayısıyla kamusal alanda çevresel sigara dumanı maruziyeti denetlenebilse de özel mekanlar için sorun olmaya devam etmektedir.

En çok öldüren, sakat birakan ve ekonomik kayiplara neden olan sigara, halk sağlıği perspektifi doğrultusunda öncelikler arasına girmektedir. $\mathrm{Bu}$ doğrultuda toplumla temas olasıllğı yüksek olan hemşirelerin, aktif ve pasif içiciliğin önlenmesi ve sigarayla ilgili mortalitenin ve morbiditenin azaltılması konusunda önemli sorumlulukları bulunmaktadır. $\mathrm{Bu}$ doğrultuda hemşirelerin sorunu ortaya koyan epidemiyolojik araştırmalar planlamaları, sigara birakma konusunda danışmanlık hizmetleri vermeleri ve toplumda farkındalık çalışmaları yürütmeleri önemlidir.

Tunceli İli'nde yetişkinlerin sigara içme davranışını ve pasif sigara dumanı maruziyetini gösteren çalışmalar oldukça sınırlıdır. Kapalı mekanlarda pasif sigara maruziyetinin büyük ölçüde ortadan kalktığı gözlemlense de işyerlerinde ve ev ortamındaki durum istatistiksel olarak ortaya konulmamıştır. Dolayısıyla bu çalışmanın amacı, Türkiye'nin doğusundaki bir kamu üniversitesinde görev alan personelin aktif ve pasif sigara içiciliği durumunu, bağımlılık düzeyini ve sigarayla ilgili içinde bulundukları değişimin aşamasını değerlendirmektir.

\section{Gereç ve Yöntem}

Tanımlayıcı türdedeki araştırmanın evrenini 2015-2016 öğretim yılında Türkiye'nin doğusunda yer alan bir kamu üniversitesinde görev yapan akademik, idari ve diğer personeller oluşturmaktadır. Çalışmada örneklem seçimine gidilmemiş olup, evrenin tamamı (yaklaşık 400 kişi) örneklem kapsamına alınmıştır. Ancak çalışmanın yürütüldüğü tarihlerde 300 çalışana ulaşılabilmiştir. Gönüllülük esası temelinde, 300 çalışanın 230'u anket formunu doldurmuştur. Böylelikle evrenin yarısından fazlasına (\%57.5) ulaşılmıştır.

Veri Toplama Araçları: Araştırmanın verileri "Üniversite Çalışanlarında Sigara Bağımlılığı Soru Formu", "Fagerström Nikotin Bağımlılık Testi" ve sigara bağımlılığ için uyarlanmış olan "Değişim Aşamalar Testi" kullanılarak toplanmıştır.

\section{Üniversite Çalışanlarında Sigara Bağımlılığı} Soru Formu: Soru formunda 26 soru yer almaktadır. İlk 9 demografik özelliklere, diğer sorular ise sigara içme alışkanlığı ve pasif sigara dumanı maruziyetini değerlendirmeye yönelik sorulardan oluşmaktadır. Araştırmanın verileri toplanmaya başlanmadan önce başka bir kurumda çalışan 10 kişi üzerinde ön uygulama yapılmıştır ve soru formuna son şekli verilmiştir.

Fagerström Nikotin Bağımlılık Testi: Fagerström nikotin bağımlılık testi bireylerde nikotinin fiziksel bağımlılığı yönünden düzeyini ve şiddetini değerlendirmek için kullanılan, 6 
sorudan oluşan, 0-1 ve 0-3 arasında ikili ve dörtlü likert tipi ölçüm sağlayan bir değerlendirme ölçeğidir. ${ }^{9}$ Türkçe formun geçerlik ve güvenirlik çalışması Uysal ve ark. (2003) tarafindan yapılmış olup ${ }^{10}$, Cronbach's alfa katsayısı 0.56 olarak bulunmuştur.

Değişim Süreçleri Ölçeği (Sigara için): Bireyin davranış değiştirmeye olan ilgisini ve motivasyonunu yansitır. Ölçek, değişimin 5 aşamas1 değerlendirmeye yöneliktir. Bireyin değişim sürecinin hangi aşamada olduğuna aşağıda yer alan sorular doğrultusunda karar verilir.

Niyet öncesi aşama: Birey sigara içmeyi sürdürmektedir ve gelecek 6 ay içinde de sigarayı bırakmayı düşünmemektedir.

Niyet Aşaması: Birey gelecek 6 ay içinde sigarayı bırakmayı düşünmektedir ancak henüz sigarayı bırakma ile ilgili bir plan yapmamıştır.

Hazırlık Aşaması: Bu aşamadaki bireyler yakın bir gelecekte (1 ay içinde) sigarayı bırakmayı planlamaktadır.

Eylem Aşaması: $\mathrm{Bu}$ aşamada bireyeler sigarayı bırakmıştır ve sigarasızlığı sürdürmek için çaba harcanmaktadır. Eylem aşması sigarayı bıraktıktan sonraki ilk altı aylık periyodu kapsar. Sürdürme Aşaması: 6 aylık bırakma sürecinden sonra ömür boyu sigarasız kalma sürecini kapsar. ${ }^{11}$

Veri Toplama Araçlarının Uygulanması: Araştırmanın verileri 6-9 Nisan 2015 tarihleri arasında anket yöntemi ile toplanmıștır. Anket formu ofislerine gidilerek katılımcilara dağıtılmış, anketin nasıl doldurulacağı konusunda açıklamalarda bulunulmuş ve bir gün sonra geri toplanmıştır. Ofislerinde ulaşılamayan çalışanlar için ikinci bir kez yeniden gidilmiş ve mümkün olduğunca çok sayıda katılımcıya ulaşılmaya çalışılmıştır.

Verilerin Analizi: Veriler bilgisayar veri tabanında SPSS 18.0 programına girilmiş, sayı, yüzdelikler kullanılarak analiz edilmiştir. Cinsiyet ve meslek ile aktif ve pasif sigara içiciliği arasında ilişki olup olmadığı ki-kare önemlilik testi kullanılarak analiz edilmiştir.

\section{Bulgular}

Bir kamu üniversitesi çalışanlarında aktif ve pasif sigara içicilik durumu, bağımlılık düzeyi ve sigarayla ilgili içinde bulundukları değişimin aşamasını değerlendirmek amaçlı yapılan bu çalışmada elde edilen bulgulara aşağıda yer almaktadır.

Çalışmaya katılan bireylerin \%37.6's1 kadın olup, \%53.9 lisans mezunu, \%50.2'si evli, \%71.1'i memurlardan oluşmaktadır. Katılımcıların yaş ortalaması $32.33 \pm 7.89^{\prime}$ dır ve \%10.9'u kronik bir hastalı̆ga sahiptir (Tablo 1).

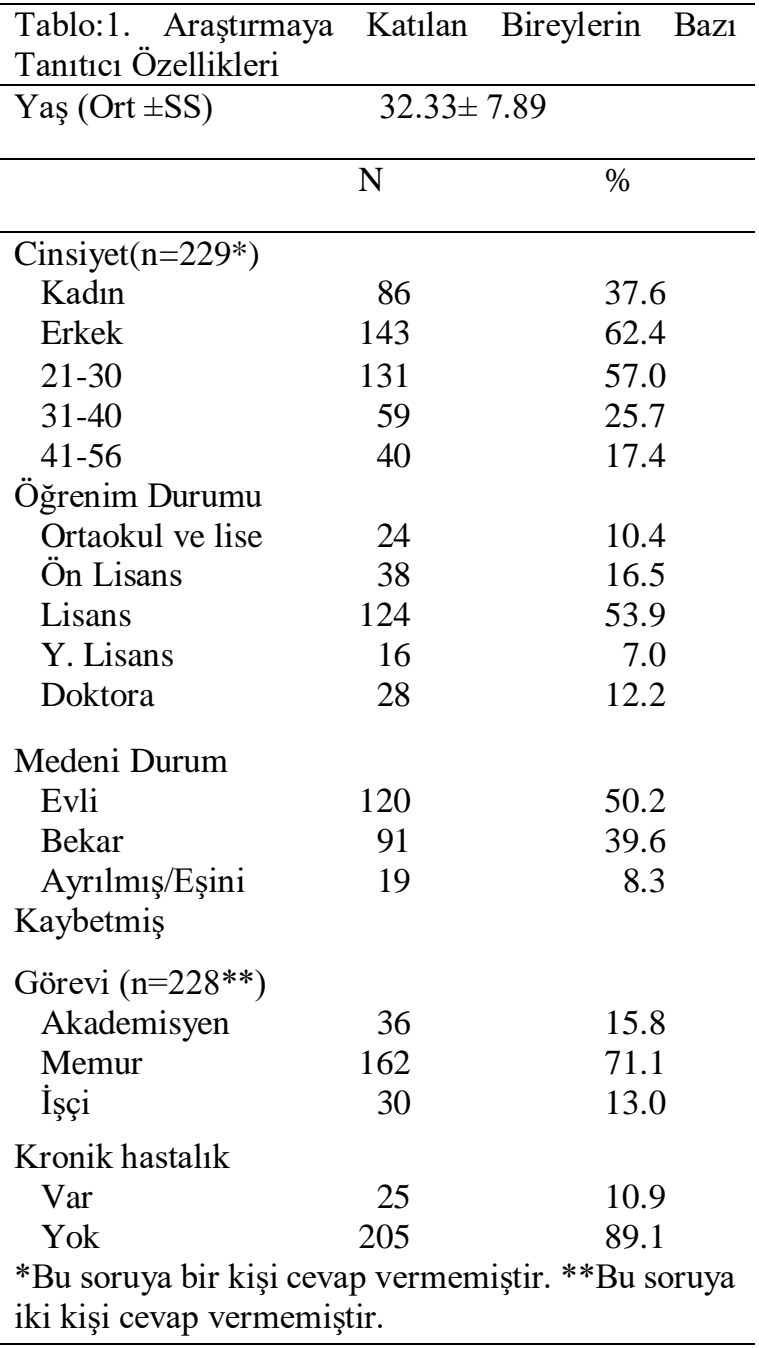

Çalışmaya katılan bireylerin \% 16.5 ' inin ara sıra, \%30.4'ünün düzenli olarak sigara içtiği, sigara içme süresinin ortalama $9.90 \pm 7.70$ y1l olduğu, sigara kullanan bireylerin \%10.8'inin sarma tütün kullandığı saptanmıştır. Sigara içme nedenlerine bakıldığında, "sigaranın rahatlattığı" düşüncesinin ilk sirada (\%48.1) yer aldığı, sigaraya ayırdıkları ortalama aylık bütçenin $234.23 \pm 109.71$ olduğu, \%17.6'sinın evinde 3 ve daha fazla sigara içicisi bulunduğu görülmüştür. Katılımcıların \% 70.4'ü evde sigara yasağı olduğunu; \%10.4'ü evde pasif sigara dumanın maruz kaldığını; \%23.9'u ise iş yerinde pasif sigara dumanına maruz kaldığını ifade etmiştir (Tablo 2). 
Araştırmaya katılan bireylerin \%57.8'si sigarayı bırakmayı düşünmediğini, $\% 58.8$ 'i sigarayı bırakmayı hiç denemediğini, \%33.3'ü sigarayı bırakma döneminde yaşayacağ 1

Tablo 2. Araştırmaya Katılan Bireylerin Aktif ve Pasif Sigara İçicilik Durumu

\begin{tabular}{|c|c|c|}
\hline Sigara içme yıl ortalaması & \multicolumn{2}{|c|}{$9.90 \pm 7.70$} \\
\hline Sigaraya ayrılan aylık bütçe & \multicolumn{2}{|c|}{$234.23 \pm 109.71$} \\
\hline & $\mathbf{N}$ & $\%$ \\
\hline $\begin{array}{l}\text { Şu anda sigara } \\
\text { durumu(n=228*) }\end{array}$ & & \\
\hline İçmiyor & 120 & 52.2 \\
\hline Ara sıra içiyor & 38 & 16.5 \\
\hline Düzenli içiyor & 70 & 30.4 \\
\hline \multicolumn{3}{|l|}{ İçilen sigara türü $(n=102)$} \\
\hline Sarma tütün & 11 & 10.8 \\
\hline Paket & 91 & 89.2 \\
\hline \multicolumn{3}{|l|}{ Sigara içme nedenleri $(n=102)$} \\
\hline Rahatlatiyor & 49 & 48.1 \\
\hline Can sıkıntısını gideriyor & 41 & 40.2 \\
\hline Sorunları unutturuyor & 12 & 11.7 \\
\hline \multicolumn{3}{|l|}{$\begin{array}{l}\text { Ailesinde sigara içen birey } \\
\text { sayısı }\left(n=159^{* *}\right)\end{array}$} \\
\hline Bir kişi & 89 & 56.0 \\
\hline İki kişi & 42 & 26.4 \\
\hline Üç kişi ve daha fazla & 28 & 17.6 \\
\hline \multicolumn{3}{|l|}{$\begin{array}{l}\text { Evde sigara yasağı bulunma } \\
\text { durumu }\end{array}$} \\
\hline Yasak var & 162 & 70.4 \\
\hline Yasak yok & 68 & 29.6 \\
\hline \multicolumn{3}{|l|}{$\begin{array}{l}\text { Evde sigara dumanına } \\
\text { maruziyet durumu }\end{array}$} \\
\hline Maruz kaliyor & 24 & 10.4 \\
\hline Maruz Kalmiyor & 206 & 89.6 \\
\hline \multicolumn{3}{|l|}{$\begin{array}{l}\text { İş yerinde sigara dumanına } \\
\text { maruziyet durumu }\end{array}$} \\
\hline Maruz kalıyor & 55 & 23.9 \\
\hline Maruz Kalmiyor & 175 & 76.1 \\
\hline
\end{tabular}

zorluklardan dolayı bırakmayı düşünmediğini, $\% 24.5$ 'i kendisi için sigarayı bırakmanın imkansız/çok zor olduğu ifade etmiştir. Katılımcıların nikotin bağımlılık düzeyi değerlendirildiğinde, \%37.6'sının orta düzeyde, \%16.8'inin ileri düzeyde bağımlılı̆̆a sahip olduğu ve çoğunluğunun sigara bırakma ile ilgili niyet öncesi (\%37.4) ve niyet aşamasında (\%30.4) olduğu görülmüştür (Tablo 3).

Katılımcılardan, kadınların erkeklere göre anlamlı ölçüde daha fazla sigara kullandığg 1 p $<$ 0.05), ayrıca akademisyenlerin sigara içme oranının diğer çalışanlardan daha yüksek olduğu ve bu farkın istatistiksel olarak anlamlı olduğu görülmüş̧ür (Tablo 4, p<0.05).

Ayrica tabloda yer almamakla birlikte katılımcıların pasif sigara dumanına maruziyet durumunun bazı değişkenlerle ilişkisine bakıldığında, diğer çalışanların, memur ve akademisyenlere göre daha fazla pasif sigara dumanına maruz kaldığı görülmüştür $(\mathrm{p}<0.05)$. Erkekler kadınlara göre daha fazla pasif sigara dumanına maruz kalmış olsalar da aradaki fark istatistiksel olarak anlamlı bulunmamıştır (Tablo 4, $\mathrm{p}>0.05)$.

Tablo 3. Katılımcıların Sigara Brrakmayla İlgili Tutum ve Davranışları (N=102)

\begin{tabular}{|c|c|c|}
\hline & $\mathrm{N}$ & $\%$ \\
\hline $\begin{array}{lll}\text { Sigarayı birakmayı } & \text { isteme } \\
\text { durumu } & & \\
\text { İstiyor } & & \\
\text { İstemiyor } & & \end{array}$ & $\begin{array}{l}43 \\
59\end{array}$ & $\begin{array}{l}42.2 \\
57.8\end{array}$ \\
\hline $\begin{array}{l}\text { Sigarayı bırakmayı deneme } \\
\text { durumu } \\
\text { Denemiş } \\
\text { Denememiş }\end{array}$ & $\begin{array}{l}42 \\
60\end{array}$ & $\begin{array}{l}41.2 \\
58.8\end{array}$ \\
\hline $\begin{array}{l}\text { Sigarayı bırakma konusunda } \\
\text { algılanan engelleyici faktörler } \\
\text { Bırakma döneminde }\end{array}$ & 34 & 33.3 \\
\hline $\begin{array}{l}\text { yasayacă̆ım zorluklar } \\
\text { Sigarayı sorun olarak görmeme } \\
\text { Sikıntı ve kaygı } \\
\text { Sigaradan hoşlanma } \\
\text { Kilo alırım düşüncesi }\end{array}$ & $\begin{array}{r}26 \\
18 \\
18 \\
6\end{array}$ & $\begin{array}{r}25.5 \\
17.7 \\
17.7 \\
5.8\end{array}$ \\
\hline $\begin{array}{l}\text { Sigara bırakmanın algılanan } \\
\text { zorluk derecesi } \\
\text { İmkansız/ çok zor } \\
\text { Belki } \\
\text { Rahatlıkla }\end{array}$ & $\begin{array}{l}25 \\
47 \\
30\end{array}$ & $\begin{array}{l}24.5 \\
46.1 \\
29.4\end{array}$ \\
\hline $\begin{array}{l}\text { Nikotin bağımlılık düzeyi } \\
\text { Düşük düzeyde bağımlılık } \\
\text { Orta düzeyde bağımlılık } \\
\text { İleri düzeyde bağımlılık }\end{array}$ & $\begin{array}{l}46 \\
38 \\
18 \\
\end{array}$ & $\begin{array}{l}45.6 \\
37.6 \\
16.8\end{array}$ \\
\hline $\begin{array}{l}\text { İçinde bulunduğu sigara bırakma } \\
\text { aşaması } \\
\text { Niyet Öncesi Aşama } \\
\text { Niyet Aşaması } \\
\text { Hazırlık Aşaması } \\
\text { Eylem Aşaması } \\
\text { Sürdürme Aşaması }\end{array}$ & $\begin{array}{r}38 \\
31 \\
30 \\
2 \\
1\end{array}$ & $\begin{array}{r}37.4 \\
30.4 \\
29.4 \\
1.9 \\
0.9\end{array}$ \\
\hline
\end{tabular}

\section{Tartışma}

Türkiye'nin doğusunda yer alan bir kamu üniversitesi çalışanlarında sigara içme alışkanlığ 1 , çevresel sigara dumanına maruziyet durumu, bağımlılık derecesi ve düzeyini belirlemek amacıyla yapılan bu çalışmada elde edilen bulgular bölgemizde sigara içme 


\begin{tabular}{|c|c|c|c|c|c|c|c|}
\hline & \multicolumn{4}{|c|}{$\begin{array}{l}\text { Sigara İçme Durumu } \\
\text { İcen }\end{array}$} & \multicolumn{2}{|c|}{ Toplam } & \multirow{2}{*}{$\begin{array}{l}\text { Önemlilik } \\
\text { testi }\end{array}$} \\
\hline & Say1 & Yüzde & Say1 & Yüzde & Say1 & Yüzde & \\
\hline Cinsiyet & & & & & & & $X^{2}=7.524$ \\
\hline Kadın & 54 & 64.3 & 30 & 35.7 & 84 & 37.0 & $\mathrm{p}=0.004$ \\
\hline Erkek & 65 & 45.5 & 78 & 54.5 & 143 & 63.0 & $\mathrm{SD}=1$ \\
\hline \multicolumn{8}{|l|}{ Meslek } \\
\hline Akademisyen & 25 & 73.5 & 9 & 26.5 & 34 & 15.0 & $X^{2}=7.248$ \\
\hline Memur & 82 & 50.6 & 80 & 49.5 & 162 & 71.7 & $\mathrm{p}=0.027$ \\
\hline İşçi & 13 & 43.3 & 17 & 56.7 & 30 & 13.3 & $\mathrm{SD}=2$ \\
\hline
\end{tabular}

durumunu ve ülkemizde uygulanan sigarasızlık politikalarının etkisini göstermesi açısından önemlidir. Ancak verilerin sadece bir üniversitede elde edilmiş olması çalışmanın sınırlılığını oluşturmaktadır.

$\mathrm{Bu}$ çalışmada, çoğunluğunu üniversite eğitimi almış orta yaş bireylerin oluşturduğu örneklemin yaklaşık 1/3'ü, düzenli olarak sigara içtiğini ifade ettiği belirlenmiştir. Bu değerlere ara sira içenler de dahil edildiğinde, üniversite çalışanlarının yarıya yakınının sigara içen bireylerden oluştuğu söylenebilir. Küresel Yetişkin Tütün Araştırması Türkiye 2012 sonuçlarına göre Türkiye'de 15 yaş üstü bireylerin \%27.1'i tütün ürünü kullanmaktadır ve kullanıcıların \%23.8'i düzenli kullanıcılardan oluşturmaktadır. ${ }^{1}$ Aydın'da 2528 katılımcı ile gerçekleştirilen bir çalışmada katılımcıların \%26.7'sinin sigara kullandığı saptanmıştır. ${ }^{13}$ Oysa 2008-2012 yıllarını kapsayan Ulusal Tütün Kontrol Programı ve Eylem Planının temel hedefi ülkemizde 15 yaş üzerindeki sigara içmeyenlerin oranını \%80'in üzerine çıkarmak iken bu hedefin tam olarak gerçekleştirilemediği görülmektedir. ${ }^{12}$ Buna rağmen Türkiye'de yetişkinlerde sigara kullanma oranları bazı dalgalanmalar gösterse de, yıllar itibariyle bakıldığında aşamalı olarak düştüğü görülmektedir. Ancak bu düşüş trendini devam ettirebilmek için tütün mücadelesindeki kararlılığın, sürdürülmesi sigaraya başlama yaşlarının geciktirilmesi gerekmektedir. Çoğunlukla ergenlik döneminde başlanan sigara, orta yaş döneminde bağımlılık düzeyinde kullanılmaya devam etmektedir.

Bu çalışmada, sigara prevalansı ile ilgili elde edilen bulgular Türkiye ortalamasından daha yüksek bulunmuştur. Özellikle akademisyenlerin sigara kullanma oranları memur- lardan ve işçilerden daha yüksekken, kadınların da erkeklerden daha fazla sigara içtiğ i görülmüştür. Genel olarak bakıldığında sigara içiciliği prevalans1, düşük sosyoekonomik, öğretim ve gelir düzeyinde, özellikle işsizlerde en yüksek oranlarda seyrettiği ifade edilmesine rağmen, ${ }^{14}$ bu çalışmada akademisyenlerin daha fazla sigara kullandığ1 görülmüștür. Bu durum tütün ürünü fiyatlarındaki artışla ilişkili olabileceği gibi, farklı iş kollarındaki stresörlerle de iliş̧ili olabilir. Ancak genel olarak değerlendirildiğinde, üniversite müfredatlarının bireylerde sağlıklı davranışlar geliştirilmesi yönünden güçlendirilmesine ihtiyaç vardır. Dünya Sağlık Örgütü verilerine göre 15 yaş üstü kadınlarda sigara kullanma oranı $\% 8$ düzeyinde iken, ${ }^{15}$ TUIKK verilerine göre Türkiye'de bu oran $\% 13.1$ düzeyindedir. $^{2}$ Kocaeli'de yürütülen bir çalışmada erkeklerde sigara içme sıklığ $\% 42.5$ olup, kadınlara göre (\%21.8) anlamlı olarak daha yüksek bulunmuştur. ${ }^{16} \mathrm{Bu}$ çalışmada kadınların sigara içme prevalansı erkeklerden daha fazla olduğu gibi, Türkiye ve dünya ortalamasının da üzerindedir. Bu durum çalışmanın yürütüldügü ilde cinsiyet rol kalıplarının diğer illere oranla görece daha fazla kırılmasından ve bu bağlamda sigaranın özgürlük alanı içerisinde bir yerlere konulmasıyla ilişkili olduğu düşünülmektedir.

Çalışma kapsamında sigaraya ayrılan aylık bütçe değerlendirilmiştir. Sigara içenler sigara satın almak için ayda ortalama olarak 146,1 TL harcamaktadır. Hanelerin yarıya yakınında da sigara içen birey sayısının birden fazla olduğu göz önünde bulundurulduğunda, sigaranın aile ekonomisine önemli bir yük bindirdiği söylenebilir. Türkiye'de sigarayla mücadele kapsamında tütün ürünü fiyatlarında artışla birlikte, bireyler bu maliyetten kaçınmak için açık tütün ve kaçak sigara kullanımına 
yönelebilmektedirler. $\mathrm{Bu}$ çalışmada sigara kullanan bireylerin 1/10'u sarma tütün kullandığını ifade etmiştir. Yanık ve ark. (2004)'nın çalışmasında kullanıcılar daha ucuz olduğu için sarma tütünü tercih ettiklerini ifade etmiştir. ${ }^{17}$ Sarma tütün kullanımı ülkemizde bölgesel düzeyde kullanılsa da, özellikle son yıllarda gençler arasında bu kullanım şeklinde artış olduğu dikkat çekmektedir. Oysa filtresiz ya da kaliteli olamayan filtrelerle kullanıldığı için sağlık açısından sarma tütün daha zararlı olabilmektedir.

Çalışma kapsamına alınan bireylerin $1 / 10$ 'u ev ortamında, yaklaşık $1 / 4$ 'ü ise iş yerlerinde çevresel sigara dumanına maruz kaldığını ifade etmiştir. Küresel Yetişkin Tütün Araştırması sonuçlarına göre Türkiye'de yetişkin bireylerin \%15.6's1 işyerinde pasif sigara dumanına maruz kalmaktadır. ${ }^{2}$ Evler ve otomobiller ise özel alan olarak görüldügünden henüz sigara yasağının girmediği alanları oluşturmaktadır. Ancak evler ve otomobillerde çocukların korunmasını sağlayacak düzenlemelere ihtiyaç vardır.

Sigara içme süresi ve sıklığg ile sigara bağımlılığının düzeyi arasında doğrusal ilişki bulunmaktadır. Sigaraya bağımlılık düzeyinin önemli göstergelerinden biri de sabah uyandıktan sonra içilen ilk sigaranın zamanıdır. Yüksek düzeyde bağımlılık geliştiren bireyler, sabah uyandıktan sonra ilk yarım saat içinde başlamak üzere daha sik sigara içmektedir ve bırakmayla ilgili daha fazla ümitsizdirler. Bu çalışmada katılımcıların \%16.8'inde ileri düzeyde bağımlılık bulunmaktadır. Türkiye genelinde ise sigara içenlerin yaklaşık yarısı günün ilk sigarasını uyandıktan sonraki ilk 30 dakika içinde içtiğini ifade etmişlerdir. ${ }^{2}$ Çalışma kapsamına alınan bireylerin yarıya yakını geçmişte sigarayı bırakmayı denemiş olup, yaklaşık 1/4'ü sigara bırakmayı "çok zor" olarak değerlendirmiştir. Katılımcıların çoğunluğu yoksunluk belirtilerini sigarayı bırakma önünde en önemli engelleyici faktör olarak değerlendirmiştir. Bütün bu veriler üniversitede sigara bırakma ile ilgili farkındalık çalışmalarına ve yönlendirmeye ihtiyaç olduğunu, üniversitelerde sağlık hizmetleri sunumunun güçlendirilmesi gerektiğine işaret etmektedir.

Sigara bırakma süreci niyet öncesi, niyet, hazırlık, eylem ve sürdürme gibi 5 aşamayı içermektedir. Niyet öncesi aşamada birey sigarayı birakmayla ilgili herhangi bir düşünceye sahip değilken, niyet aşamasında sigara bırakmayı düşünmeye başladığı, hazırlık aşamasında ise 30 gün içinde bırakmayı planladığı bir dizi süreci takip etmektedir. Velicer'e göre toplumun \%80'i niyet öncesi ya da niyet aşamasında yer almaktadır. ${ }^{18} \mathrm{Bu}$ çalışmada da katılımcıların çoğunluğu sigarayı bırakma ile ilgili niyet öncesi ya da niyet aşamasında olduğunu ifade etmiştir. Kocaeli'de geniş bir örneklem grubu ile yürütülen bir çalışmada 18 yaş üzeri halen sigara içen bireylerin \%67.7'si daha önce sigarayı bırakmayı denediğini, sigara bırakmayı deneme girişiminin en s1k nedeninin yaşanan sağlık sorunları olduğu görülmüştür. ${ }^{16}$ Sigara birakma çalışmaları bireyin içerisinde bulunduğu aşamaya göre planlanmalıdır. Bu nedenle değişime bireyin bulunduğu yerden başlamak gerekir. $\mathrm{Bu}$ doğrultuda niyet öncesi aşamada olan bir bireye uygulanacak motivasyonel teknikler ile hazırlık aşamasında olan bir bireye uygulanacak teknikler birbirinden farklıdır. ${ }^{11} \mathrm{Bu}$ çalışmanın bulgularından da görüldüğü gibi katılımcıların çoğu sigara içme davranışını sürdürme eğilimindedir ve bir sonraki aşamaya geçmelerini sağlamak için süreklilik arz eden farkındalık çalışmaları yürütülmelidir.

\section{Sonuç}

Bir üniversite çalışanlarında aktif ve pasif sigara içme prevalansı ve etkileyen faktörleri anlamak için yapılan bu çalışmadan elde edilen bulgulara göre üniversite çalışanlarının yarıya yakının aktif sigara içicisi olduğu, önemli bir kısmının işyerlerinde ve evde pasif sigara dumanına maruz kaldığı, kadınlarda ve akademisyenlerde sigara içme oranları daha fazla iken, diğer çalışanların pasif sigara dumanına daha fazla maruz kaldıkları görülmüştür.

$\mathrm{Bu}$ sonuçlar doğrultusunda, üniversitelerde sağlı birimleri tarafından sürekliliği olan farkındalık çalışmalarının başlatılması ve sürdürülmesi, pasif içiciliği önlemek için ilgili mevzuatların kararlılıkla uygulanması önerilmektedir.

\section{Teşekkür}

Çalışmaya veri toplama aşamasında katkı sunan, Hemşirelik 4. Sınıf öğrencisi Demet DÜZGÜNER ve Jiyan YAĞMUR'a teşekkür ederiz.

Etik Komite Onayı: Yazarlar çalışmanın World Medical Association Declaration of Helsinki "Ethical Principles for Medical Research Involving Human Subjects", (amended in October 2013) prensiplerine uygun olarak yapıldığını beyan etmişlerdir. 


\section{Kaynaklar}

1. World Health Organization (WHO). Global Report On Trends İn Prevalence Of Tobacco Smoking. 2015. [Updated 2015; cited 2017 May 18]. Available from http://apps. who.int/iris/bitstream/10665/156 262/1/9789241564922_eng.pdf?ua=1

2. Sağlık Bakanlığı. Küresel Yetişkin Tütün Araştırmas1 Türkiye 2012. Sağlık Bakanlığı, Ankara, 2014, Yayın No:948.

3. CDC. How Tobacco Smoke Causes Disease. 2010. [Updated 2016; cited 2017 May 18]. Available from https://www.cdc.gov/tobacco/data_statistics /sgr/2010/consumer_booklet/pdfs/consumer .pdf

4. World Health Organization (WHO). Report on the Global Tobacco Epidemic. Geneva, 2008.

5. Doğanay S, Sözmen K, Kalaça S, Ünal B. Türkiye'de toplumda sigara içme sıklığ nasıl değişiyor? Türkiye Halk Sağlığı Dergisi 2012;10(2):93-115.

6. CDC. Second Hand Smoke (SHS) Facts. 2017. [Updated 2017; cited 2017 May 24]. Available from https://www.cdc.gov/tobacco/data_statistics /fact_sheets/secondhand_smoke/general_fa cts/

7. Battal S, Güneş G, Açık Y. Elazı̆̆ merkez bölgesinde kadınların çevresel sigara dumanına maruziyeti ve bu konudaki bilgi ve tutumları. İnönü Üniversitesi Tip Fakültesi Dergisi 2009;16(3):149-156.

8. Karatay G. Kars ili 4 no'lu sağlık ocağına kayıtlı 0-6 yaş aralığındaki bebek ve çocuklarda pasif sigara dumanı maruziyetinin belirlenmesi. C.Ü. Hemşirelik Yüksekokulu Dergisi 2008;12(2):31-38.

9. Fagerstrom KO, Heatherton TF, Kozlowski LT. Nicotine addiction and its assessment. Ear Nose Throat J. 1992;69:763-767.
10. Uysal MA, Kadakal F, Karşidăg C, Bayram NG, Uysal O, Yilmaz V. Fagerström test for nicotine dependence: reliability in a Turkish sample and factor analysis. Tuberk Toraks 2004;52:115-121.

11. Prochaska JO, DiClemente CC, Norcross JC. In search of how people change, application to addictive behaviours. American Psychologist 1992;47:1102-1114.

12. T.C. Türkiye İstatistik Kurumu Başkanlığ 1 (TÜİK). Küresel Yetişkin Tütün Araştırmas1, 2012. Sayı:13142, 31.08.2012. [cited June 2017]. Available from http://www.tuik.gov.tr/PreHaberBultenleri. do?id=13142.

13. Bektaş Uysal H, Yaşar MB, Sönmez Hulki M. Aydın'da sigara içiminin ve hipertansiyonla birlikteliğinin son 20 yıldaki değişimi. Türkiye Aile Hekimliği Dergisi2016;20(2):54-63.

14. Hiscock R, Bauld L, Amos A, Fidler JA, Munafò M. Socioeconomic status and smoking: A review. Ann N Y Acad Sci. 2012;1248:107-123.

15. WHO. World Health Statistics 2013. Geneva: World Health Press, 2013.

16. Barış SA, Yıldız F, Başyiğit İ, Boyacı H. Kocaeli'de sigara içme prevalans1. Tüberküloz ve Toraks Dergisi 2011;59(2):140-145.

17. Yanık M, Gencer M, Ceylan E, Altındağ A. Şanlıurfa'da "sarma tütün" kullanan bir grupta sosyodemografik özellikler ve bağımlılık düzeyleri. Bağımlılık Dergisi 2004;5(1):26-29.

18. Velicer, W.F., Prochaska, J.O., Bellis, J.M., DiClemente, C.C., Rossi, J.S., Fava, J.L. ve diğerleri (1993). An Expert System İntervention for Smoking Cessation. Addictive Behaviors, 18, 269-290. 